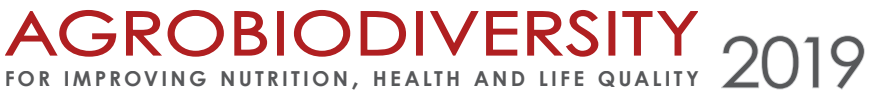

(3)

\section{CHANGE OF CELLS AND LAYERS SIZES OF HEMP (CANNABIS SATIVA L.) BAST FIBERS IN THE SYNTHETIC BREEDING PROCESS}

\author{
Mishchenko Serhii* \\ Institute of Bast Crops of NAAS of Ukraine, Hlukhiv, Ukraine
}

Received: 4. 6. 2019 Revised: 28. 10. 2019 Published: 30. 11. 2019

The sizes (length and width) of cells and layers of primary and secondary bast fibers of hemp (Cannabis sativa L.) were reduced due to self-pollination (the phenomenon of inbred depression). The average length of the primary bast fibers cells decreased from 66.15 to $60.45 \mu \mathrm{m}$ and cell width decreased from 40.05 to $36.30 \mu \mathrm{m}$. The average length of the secondary bast fibers cells decreased from 26.55 to $21.75 \mu \mathrm{m}$ and cell width decreased from 15.75 to $14.25 \mu \mathrm{m}$. The values of these anatomical characteristics have increased as a result of free pollination and hybridization of inbred lines and the creation of a synthetic population (the phenomenon of heterosis). The sizes of the primary bast fibers cells in synthetic population plants were $73.95 \times 47.40 \mu \mathrm{m}$ and the sizes of the secondary bast fibers cells was $32.70 \times 22.05 \mu \mathrm{m}$. The thickness of the primary fiber layer in the Hlukhivsky 58 variety was 230.25 , inbred lines were 155.25 , and the synthetic population was $264.00 \mu \mathrm{m}$. The thickness of the second fiber layer was 99.75, 77.25 and $116.75 \mu \mathrm{m}$, the total thickness of the fiber layer was 330.00, 232.50 and $380.75 \mu \mathrm{m}$, respectively. The proposed method for the creation of synthetic populations of monoecious hemp by the scheme "variety - inbred lines - synthetic population" is effective at increasing the fiber content of plants.

Keywords: hemp, inbreeding, synthetic breeding, fiber, cell

\section{Вступ}

Коноплі посівні (Cannabis sativa L.) після певного періоду забуття набувають все більшої популярності і поширення як сільськогосподарська культура комплексного використання, основними напрямами якого $€$ волокнистий, насіннєво-олійний, біоенергетичний і медичний, однак традиційно вони є луб'яною рослиною, у зв'язку з чим розроблені дієві методи і способи селекції, які дали змогу суттєво збільшити вміст волокна в стеблах (Laiko, 2012; Vyrovets, 2015). Ось чому вивченню анатомічної будови поперечного зрізу стебла і волокнистого шару зокрема, завжди приділялась значна увага, що дозволяло встановити чинники формування високої кількості і якості волокна в онтогенезі та виявити цінні генотипи.

\footnotetext{
*Corresponding author: Mishchenko Serhii, Institute of Bast Crops of NAAS of Ukraine, Tereshchenkiv 45, 41400 Hlukhiv, Ukraine $\triangle$ serhii-mishchenko@ukr.net
} 
Особливістю анатомічної будови $є$ те, що коноплям властиве формування первинного і вторинного лубу. Первинний луб (флоема) розміщений за первинною твірною тканиною перициклом (перикамбієм), внаслідок діяльності якого він і виникає. Флоема складається із ситоподібних (решітчастих) трубок, товстостінних прозенхімних клітин первинних луб'яних волокон і тонкостінних клітин луб'яної (флоемної) паренхіми. Первинні луб'яні волокна мають довжину до 50-75 мм і зливаються у суцільне кільце пучків. Тип пучків - колатеральні, складні, відкриті, розміщені в одне коло. За первинним лубом залягає вторинний луб (вторинна кора), що також складається з ситоподібних трубок, вторинних луб'яних волокон і луб'яної паренхіми. Вторинне волокно має довжину не більше 4 мм. За луб'яною паренхімою залягає вузька смужка генеративної тканини - камбію, внаслідок діяльності якого відбувається перехід до вторинної будови (Myhal, 2011).

Волокнисті пучки конопель (часто вони зливаються у суцільне кільце) складаються 3 окремих клітин, які називаються елементарними волокнами. У більшості випадків луб'яні волокна мають веретеноподібну форму з загостреними чи злегка притупленими кінцями. Важливими ознаками елементарних волокон $є$ форма, розмір клітини (діаметр, або довжина і ширина) та каналу, товщина оболонок та їх шаруватість. Вони значною мірою визначають якісні показники волокна як сировини для переробної промисловості (Myhal, 2011).

Розміри клітин первинних луб'яних волокон на поперечному зрізі у середньому становлять від 5 до 55 мкм, а вторинних - від 10 до 20 мкм. Характерною особливістю конопель $€$ шаруватість оболонки елементарних волокон. Первинна оболонка впритул прилягає до серединної пластинки й органічно поєднується з нею. Первинна оболонка тонка й не буває шаруватою. Вторинна оболонка складає основну масу клітини луб'яних волокон. Вона виникає за первинною оболонкою і має шарувату структуру, що значно потовщує їі (Myhal, 2011). Вторинна клітинна оболонка $є$ нерівномірною за складом і структурою. У ній виділяють три відмінні шари, умовно позначені як S1, S2 і S3. Після відкладання шару S1, товщина якого залишається незмінною протягом усього періоду формування вторинної оболонки, відкладається шар S3, який потім модифікується в S2, що певний час збільшується. Отже, формування вторинної оболонки супроводжується інтенсивною модифікацією новоутворених шарів. Інтрузивний ріст волокон у довжину передує утворенню вторинної клітинної оболонки, а не поєднується з ним, як вважали раніше. Саме формування потовщеної клітинної оболонки дозволяє рослинним волокнам набувати міцності, необхідної для реалізації їх механічних функцій (Chernova, 2007; Snegireva et al., 2015; Chernova et al., 2018).

До фази бутонізації у стеблах конопель спочатку формується більш якісне первинне волокно, а з початком закладання генеративних органів спостерігається утворення гіршого за якістю вторинного волокна, хоча у жіночих і однодомних рослин ініціація росту вторинного волокна може розпочинатися раніше (Mediavilla et al., 2001). На ранніх стадіях онтогенезу клітини вторинних луб'яних волокон зустрічаються лише внизу стебла, суттєве утворення вторинного волокна спостерігається на початку цвітіння або при досягненні рослиною висоти більше 2,25 м і/або діаметра більшого за 
1 см (Hernandez, 2007). Кількість клітин первинних луб'яних волокон на поперечному зрізі стебла зростає приблизно аж до початку суцвіття, а потім зменшується, а кількість клітин вторинних луб'яних волокон поступово зменшується від другого міжвузля, і приблизно в зоні початку суцвіття вторинне волокно стає відсутнім (Chernova, 2007; Snegireva et al., 2015).

У селекції на підвищення волокнистості (маси і вмісту волокна) використовуються різні методи і прийоми. Одним із шляхів створення нового селекційного матеріалу в цілому і збільшення вмісту волокна в стеблах конопель зокрема $є$ створення самозапилених ліній (Layko et al., 2000; Mishchenko and Laiko, 2013) та подальша їх міжлінійна, сортолінійна і лінійносортова гібридизація з добором в гібридних популяціях. Доведено, що таким гібридам характерні ефект гетерозису за багатьма цінними господарськими ознаками (Mishchenko, 2016а), порівняно висока стабільність ознаки однодомності (Mishchenko, 2015) і відсутності канабіноїдних сполук (Mishchenko, 2016b) як на ранніх етапах селекції, так і в процесі подальшого розмноження. Важливе значення при цьому відіграє оптимальний підбір компонентів схрещувань на основі встановлення комбінаційної здатності різних самозапилених ліній (Mishchenko, 2017), що суттєво може підвищити продуктивність.

Разом з тим, інбридинг конопель може бути використаний з метою очищення популяції від одного або декількох небажаних рецесивних алелів і стабілізації таким чином певних селекційних ознак чи їх комплексу в існуючому селекційному матеріалі (сорті) шляхом створення однорідних самозапилених ліній з наступним об'єднанням їх в єдину синтетичну популяцію. Комбінація (суміш) самозапилених ліній рідко використовується як метод для покращення перехреснозапильних культур, тому що потомство, яке утворюється у результаті самозапилення, зазвичай має низьку життєздатність насіння, також при комбінації самозапилених ліній спостерігається тенденція до збільшення частки рослин, схильних до самозапилення (Briggs and Noulz, 1972). Не зважаючи на це, даний метод існує і може застосовуватися на практиці, зокрема не тільки для поліпшення селекційного матеріалу, а й для створення нового, оскільки в процесі близькоспорідненого розмноження популяція диференціюється за багатьма ознаками на низку самозапилених ліній, які мають досить суттєві відмінності порівняно з вихідною формою.

Мета і завдання дослідження - встановити особливості зміни розмірів (довжини i ширини) клітин та шарів первинних і вторинних луб'яних волокон в процесі синтетичної селекції, яка здійснюється за схемою «сорт - самозапилені лінії синтетична популяція».

\section{Матеріали та методи}

\section{Вихідний матеріал та методика створення синтетичних популяцій}

Для самозапилення добирали селекційні сім'ї сорту однодомних конопель Глухівські 58 з бажаними ознаками чи їх комплексом (у даному випадку з високими показниками загальної довжини і маси стебла, маси і вмісту волокна). Насіння 
висівали в умовах вегетаційного будинку, рослини ізолювали до цвітіння індивідуальними ізоляторами з агроволокна. Самозапилення проводили протягом 4-6 поколінь до настання інбредного мінімуму, отримання однорідних та стабільних ліній. Паралельно із самозапиленням здійснювали вивчення інбредних ліній у розсаднику оцінки за основними селекційними ознаками за площі живлення рослин $30 \times 5$ см. Для розмноження добирали лінії з наступними характеристиками: найменший ступінь депресії, відсутність шкідливих мутацій і морфозів, бажаний рівень прояву селекційних ознак, відсутність у потомстві рослин з канабіноїдними сполуками, переважання у статевому складі однодомної фемінізованої матірки та відсутність плосконі однодомних конопель. Решту самозапилених ліній вибраковували. На завершальних етапах близькоспорідненого розмноження залишали лише ті лінії, які в результаті самозапилення утворювали найменшу кількість насіння, а за даними розсадника оцінки за умови відсутності просторової ізоляції і вільного запилення пилком різного походження характеризувалися високою насіннєвою продуктивністю. Такий підхід дозволяв добирати генотипи, які меншою мірою здатні до самозапилення, а більшою мірою - до перехресного запилення (чи самонесумісності), що у майбутньому підвищувало життєздатність і продуктивність потомства. Для отримання синтетичної популяції проводили вільне схрещування кращих 5-7 самозапилених ліній, досить подібних одна до одної. Для цього їх висівали в умовах вегетаційного будинку у двократній повторності з випадковою послідовністю на ділянці розміром 2,5 × 2,5 м, яку перед цвітінням ізолювали груповим ізолятором. Отримували насіння syn-1. У розсаднику оцінки вивчали потомство кожної лінії за комбінаційною здатністю, на основі чого для отримання наступного покоління синтетичної популяції з кожної лінії (як правило, використовували 3-5 ліній), що добре себе зарекомендувала за досліджуваними ознаками і властивостями, добирали однакову кількість (масу) насіння, змішували і висівали для отримання syn-2 і потім syn-3.

\section{Анатомічний аналіз}

Для анатомічного аналізу відбирали типові стебла конопель з однаковим діаметром (1 cм) у фазу початку дозрівання насіння - код за шкалою BBCH 81 (Mishchenko et al., 2017), коли волокно повністю сформоване. Площа живлення рослин $30 \times 5$ см. Зі стебла живих рослин конопель на рівні четвертого міжвузля брали відрізок кори з частиною деревини завдовжки 2-3 см. За допомогою гострого леза готували поперечні зрізи та тимчасові анатомічні препарати. Анатомічний аналіз волокнистих структур стебел конопель, зокрема довжину і ширину клітин та товщину шарів первинних і вторинних луб'яних волокон, проводили з використанням мікроскопа при збільшенні в 600, 300 та 150 разів. Виміри здійснювали за допомогою окуляр-мікрометра з умовними поділками (умовними одиницями), які потім виражали в мікрометрах (мкм). Проводили по 10 вимірювань 10 стебел сорту, самозапилених ліній і синтетичної популяції. 


\section{Статистичний аналіз}

Статистичну обробку експериментальних даних проведено за параметрами варіаційної статистики (середнє арифметичне, похибка вибіркового середнього, коефіцієнт варіаціi) та $t$-критерієм Стьюдента (Dospekhov, 1973).

\section{Результати та їх обговорення}

У поколіннях від самозапилення рослин однодомних конопель, як правило, спостерігається явище інбредної депресії, яке супроводжується зменшенням показників селекційних ознак, появою мутацій та морфозів (Mishchenko, 2011), зміною статевої структури (Mishchenko, 2013). Воно продовжується до настання інбредного мінімуму, який у конопель, залежно від ознаки, наступає у 3-6 поколінні. У окремих сімей різко виражена інбредна депресія не спостерігається або ж продуктивність знижується не на достовірному рівні значимості. Ці ж закономірності характерні і для ознак волокнистості: довжини і діаметру стебла, маси стебла і волокна, вмісту волокна (Mishchenko and Laiko, 2013).

Ефективність створення синтетичних популяцій однодомних конопель 3 метою поліпшення існуючого селекційного матеріалу (сорту) чи створення нового не викликає сумнівів. Так, у синтетичної популяції, створеної на основі вільного запилення інбредних ліній за описаною експериментальною методикою, відбувається підвищення ознак продуктивності і навіть гетерозисний ефект, який полягає у перевищенні вихідних форм (сортів) за ознаками довжини стебла (264,0 порівняно з 223,9 см), маси стебла (18,23 і 17,84 г), маси волокна $(6,05$ і 5,62 г) і вмісту волокна (33,53 і 32,70 \%) (Таблиця 1). Разом з тим логічно виникає питання, за рахунок чого змінюються ознаки волокнистості, зокрема кількість чи вміст волокна у рослинах. Відповідь на це проблемне питання дає анатомічний аналіз поперечного зрізу стебла, а саме - встановлення розмірів клітин первинних і вторинних луб'яних волокон, товщини шарів первинного і вторинного волокна, які в сукупності з висотою рослин, технічною довжиною (частиною стебла до зони суцвіття) і діаметром стебла формують продуктивність рослин конопель за волокном, що було передбачено наступним етапом наших досліджень.

Порівняно з вихідним сортом Глухівські 58, у самозапилених ліній спостерігається тенденція до зменшення розмірів клітин елементарних луб'яних волокон. Довжина клітин первинних луб'яних волокон у середньому зменшується з 66,15 до 60,45 мкм, ширина - 3 40,05 до 36,30 мкм. Довжина клітин вторинних луб'яних волокон у середньому зменшується з 26,55 до 21,75 мкм, ширина - 3 15,75 до 14,25 мкм. У синтетичної популяції встановлено збільшення розмірів досліджуваних клітин. Вони $з$ високою достовірністю перевищують не тільки показники самозапилених ліній, а й сорту. Так, довжина клітин первинних луб'яних волокон у рослин синтетичної популяції становила 73,95, ширина - 47,40 мкм, вторинних луб'яних волокон - 32,70 і 22,05 мкм відповідно (Таблиця 2). 
Таблиця 1 Зміна ознак волокнистості конопель сорту Глухівські 58 в процесі синтетичної селекції

Table 1 Changes in the characteristics of the fiber content of the Hlukhivsky 58 hemp variety in the synthetic breeding process

\begin{tabular}{|c|c|c|c|c|c|c|c|c|}
\hline \multirow[t]{3}{*}{ Варіант } & \multicolumn{8}{|c|}{ Ознаки } \\
\hline & \multicolumn{2}{|c|}{$\begin{array}{c}\text { довжина стебла } \\
\text { (см) }\end{array}$} & \multicolumn{2}{|c|}{ маса стебла (г) } & \multicolumn{2}{|c|}{ маса волокна (г) } & \multicolumn{2}{|c|}{ вміст волокна (\%) } \\
\hline & $\bar{x} \pm s_{\bar{x}}$ & $V(\%)$ & $\bar{x} \pm s_{\bar{x}}$ & $V(\%)$ & $\bar{x} \pm s_{\bar{x}}$ & $V(\%)$ & $\bar{x} \pm s_{\bar{X}}$ & $V(\%)$ \\
\hline Сорт & $223,9 \pm 4,57$ & 9,1 & $17,84 \pm 1,284$ & 34,6 & $5,62 \pm 0,412$ & 40,7 & $32,70 \pm 0,616$ & 7,7 \\
\hline $\begin{array}{l}\text { Самозапилена } \\
\text { лінія }\end{array}$ & $212,9 \pm 6,02$ & 11,0 & $16,74 \pm 1,824$ & 42,2 & $5,49 \pm 0,608$ & 42,9 & $32,72 \pm 0,413$ & 4,9 \\
\hline $\begin{array}{l}\text { Синтетична } \\
\text { популяція }\end{array}$ & $264,0 \pm 4,02$ & 5,9 & $18,23 \pm 1,214$ & 25,8 & $6,05 \pm 0,371$ & 23,7 & $33,53 \pm 0,712$ & 8,9 \\
\hline
\end{tabular}

Примітка: $\bar{x}$ - середнє арифметичне; $s_{\bar{X}}$ - похибка вибіркового середнього; $V(\%)$ - коефіцієнт варіації

Таблиця 2 Зміна розмірів клітин елементарних луб'яних волокон на поперечному зрізі стебла конопель сорту Глухівські 58 в процесі синтетичної селекції

Table 2 Change of the sizes of elemental bast fibers cells on the stem cross-section of the Hlukhivsky 58 hemp variety in the synthetic breeding process

\begin{tabular}{|c|c|c|c|c|c|c|c|c|}
\hline \multirow[t]{4}{*}{ Варіант } & \multicolumn{8}{|c|}{ Розміри клітин первинних луб'яних волокон, мкм } \\
\hline & \multicolumn{4}{|c|}{ первинних } & \multicolumn{4}{|c|}{ вторинних } \\
\hline & \multicolumn{2}{|c|}{ довжина } & \multicolumn{2}{|c|}{ ширина } & \multicolumn{2}{|c|}{ довжина } & \multicolumn{2}{|l|}{ ширина } \\
\hline & $\overline{\boldsymbol{x}} \pm s_{\bar{x}}$ & $V(\%)$ & $\overline{\boldsymbol{x}} \pm s_{\bar{x}}$ & $V(\%)$ & $\bar{x} \pm s_{\bar{x}}$ & $V(\%)$ & $\overline{\boldsymbol{x}} \pm s_{\bar{x}}$ & $V(\%)$ \\
\hline Сорт & $66,15 \pm 2,980$ & 20,1 & $40,05 \pm 1,901$ & 21,2 & $26,55 \pm 1,255$ & 21,1 & $15,75 \pm 0,718$ & 20,4 \\
\hline $\begin{array}{l}\text { Самозапилена } \\
\text { лінія }\end{array}$ & $60,45 \pm 2,222$ & 16,4 & $36,30 \pm 1,150$ & 14,2 & $21,75 \pm 0,894$ & 18,4 & $14,25 \pm 0,481$ & 15,1 \\
\hline $\begin{array}{l}\text { Синтетична } \\
\text { популяція }\end{array}$ & $73,95 \pm 2,898$ & 17,5 & $47,40 \pm 2,626$ & 24,8 & $32,70 \pm 1,845$ & 25,2 & $22,05 \pm 1,603$ & 32,5 \\
\hline$P_{1-2}$ & \multirow{3}{*}{\multicolumn{2}{|c|}{$P<0,001$}} & \multicolumn{6}{|c|}{$P<0,01$} \\
\hline$P_{2-3}$ & & & \multicolumn{2}{|c|}{$P<0,001$} & \multicolumn{2}{|l|}{$P<0,001$} & \multicolumn{2}{|l|}{$P<0,001$} \\
\hline$P_{1-3}$ & & & \multicolumn{2}{|l|}{$P<0,05$} & \multicolumn{2}{|l|}{$P<0,01$} & \multicolumn{2}{|l|}{$P<0,001$} \\
\hline
\end{tabular}

Примітка: $\bar{x}$ - середнє арифметичне; $s_{\bar{X}}-$ похибка вибіркового середнього; $V(\%)$ - коефіцієнт варіації; $(P)$ - рівень значимості

Аналогічно зменшується товщина і кількість вторинних оболонок первинних і вторинних клітин луб'яних волокон, які значною мірою детермінують якість волокна для промислового виробництва.

Відомо, що якісне волокно конопель визначають правильно сформовані елементарні волокна, які мають округлу чи ізодіаметричну форму, невеликий діаметр клітин, опуклий контур оболонки (без зиґзагів), малий канал (точковий або щілиноподібний), товсту оболонку з помірно рідкою шаруватістю і компактне з'єднання волокон в пучках (Myhal, 2011). 
Також установлено, що у процесі створення вихідного матеріалу за схемою «сорт самозапилені лінії - синтетична популяція» змінюється товщина волокна на поперечному зрізі стебла. У результаті інбридингу вона зменшується, а у результаті вільного самозапилення при створенні синтетичної популяції - збільшується. Товщина шару первинного волокна у сорту Глухівські 58 становила 230,25, самозапилених ліній - 155,25, синтетичної популяції - 264,00 мкм, вторинного волокна - 99,75, 77,25 і 116,75 мкм, загальна товщина шару волокна - 330,00, 232,50 і 380,75 мкм відповідно. За досліджуваними ознаками різниця між сортом і самозапиленими лініями, самозапиленими лініями і синтетичною популяцією, вихідним сортом і синтетичною популяцією за невеликим винятком є достовірною на високому рівні значимості (Таблиця 3).

Таблиця 3 Зміна товщини шару волокна на поперечному зрізі стебла конопель сорту Глухівські 58 в процесі синтетичної селекції

Table 3 Change of the thickness of the fiber layer on the stem cross-section of the Hlukhivsky 58 hemp variety in the synthetic breeding process

\begin{tabular}{lccccc}
\hline \multirow{2}{*}{ Варіант } & \multicolumn{4}{c}{ Товщина шару волокна, мкм } \\
\cline { 2 - 5 } & \multicolumn{2}{c}{ первинного } & \multicolumn{1}{c}{ вторинного } & загальна \\
\cline { 2 - 5 } & $\overline{\boldsymbol{x}} \pm \boldsymbol{s}_{\overline{\boldsymbol{x}}}$ & $\boldsymbol{V}(\boldsymbol{\%})$ & $\overline{\boldsymbol{x}} \pm \boldsymbol{s}_{\overline{\boldsymbol{x}}}$ & $\boldsymbol{V}(\%)$ & $\overline{\boldsymbol{x}}$ \\
\hline Сорт & $230,25 \pm 8,992$ & 17,5 & $99,75 \pm 4,900$ & 22,0 & 330,00 \\
Самозапилена лінія & $155,25 \pm 8,236$ & 23,7 & $77,25 \pm 4,390$ & 25,4 & 232,50 \\
Синтетична популяція & $264,00 \pm 10,347$ & 17,5 & $116,75 \pm 8,186$ & 31,4 & 380,75 \\
$\boldsymbol{P}_{\mathbf{1 - 2}}$ & $P<0,001$ & & $P<0,01$ & \\
$\boldsymbol{P}_{\mathbf{2 - 3}}$ & $P<0,001$ & & & \\
$\boldsymbol{P}_{\mathbf{1 - 3}}$ & $P<0,05$ & & & - \\
\hline
\end{tabular}

Примітка: $\bar{x}$ - середнє арифметичне; $s_{\bar{X}}$ - похибка вибіркового середнього; $V(\%)$ - коефіцієнт варіації; $P$ - рівень значимості.

Порівняно з іншими генотипами, для сорту Глухівські 58 та селекційного матеріалу, створеного з його використанням, характерні досить великі розміри клітин луб'яних волокон. Зауважимо, що ознаки як волокнистого шару в цілому, так і окремих клітин луб'яних волокон зокрема, у сортів і колекційних зразків конопель різного генетичного походження характеризуються високим ступенем мінливості, тому у селекційних дослідженнях проблема їх подальшого вивчення залишається актуальною (Kryvosheieva, 2000; Onupriienko, 2008b; Myhal, 2011; Mishchenko and Kmets, 2017). Особливо виявлено значні відмінності в анатомічній будові, розмірах та розміщенні клітин елементарних волокон та шарів первинного і вторинного волокна у рослин високоволокнистих сортів, порівняно з низьковолокнистими (Kryvosheieva, 1999; Onupriienko, 2008a). Виходячи з цього, аналіз анатомічної будови стебла конопель до цвітіння може бути використано у практичній селекції, наприклад, при доборі рослин у селекційних розсадниках (Laiko et al., 2013) або у фазу біологічної стиглості для визначення якості волокна за непрямими ознаками - формою, розмірами, будовою 
вторинних оболонок і каналу клітин елементарних волокон та співвідношенням товщини шарів більш якісного первинного волокна, порівняно з більш грубим вторинним тощо.

У самозапилених ліній відбувається зменшення розмірів клітин елементарних волокон (особливо первинних), товщини шарів залягання волокна і маси волокна з рослин. Ступінь інбредної депресії у кожному конкретному випадку залежить від генотипу селекційного матеріалу. Зменшення маси волокна з рослини під впливом близькоспорідненого розмноження може відбуватися як шляхом зменшення розмірів клітин елементарних волокон, так і кількості таких клітин (і відповідно товщини шару волокна), або залежати від обох вказаних явищ одночасно (Mishchenko et al., 2015). Нашими дослідженнями установлено, що у конопель в процесі самозапилення відбувається депресія, а в результаті вільного запилення інбредних ліній і створення синтетичної популяції внаслідок отримання високогетерозиготних організмів спостерігається явище гетерозису не лише за морфологічними, а й анатомічними ознаками, які у своїй сукупності підвищують волокнистість селекційного матеріалу.

\section{Висновки}

Запропоновано i апробовано методику створення синтетичних популяцій однодомних конопель. У результаті самозапилення зменшуються розміри (довжина і ширина) клітин та шарів первинних і вторинних луб'яних волокон (явище інбредної депресії), а в результаті вільного запилення інбредних ліній і створення синтетичної популяції спостерігається збільшення величини даних ознак (явище гетерозису). Волокнистість рослин змінюється внаслідок сукупного впливу морфологічних і анатомічних ознак.

\section{Подяка}

Автор висловлює щиру подяку кандидату сільськогосподарських наук Ірині Кмець за сприяння у проведенні досліджень.

\section{Література}

BRIGGS, F., NOULZ, P. 1972. Nauchnye osnovy selektsii rasteniy [Scientific basis of plant breeding]. Moskva : Kolos. 339 p. [In Russian].

CHERNOVA, T.E. 2007. Biogenez floemnykh volokon konopli (Cannabis sativa L.) il'na (Linum usitatissimum L.): sravnitel'nyy analiz [Biogenesis of phloem hemp fibers (Cannabis sativa L.) and flax (Linum usitatissimum L.): a comparative analysis] : dissertation theses. Kazan', 24 p. [In Russian].

CHERNOVA, T.E. et al. 2018. Development of distinct cell wall layers both in primary and secondary phloem fibers of hemp (Cannabis sativa L.). In Industrial Crops and Products, vol. 117, p. 97-109. https://doi.org/10.1016/j.indcrop.2018.02.082

DOSPEKHOV, B.A. 1973. Metodika polevogo opyta [Methods of field experience]. 3-e izd. Moskva : Kolos. 336 p. [In Russian].

HERNANDEZ, A., WESTERHUIS, W., van DAM, J.E.G. 2007. Microscopic study on hemp bast fibre formation. In Journal of Natural Fibres, vol. 3(4), p. 1-12. https://doi.org/10.1300/J395v03n04 01 
KRYVOSHEIEVA, L.M. 1999. Pro spivvidnoshennia osnovnykh anatomichnykh struktur stebla nyzkovoloknystykh i vysokovoloknystykh sortiv konopel [On the correlation of the basic anatomical structures of the stem of low-fiber and high-fiber hemp varieties]. In Proceedings of the Institute of Agriculture of UAAS, vol. 1-2, p. 5-8 [In Ukrainian].

KRYVOSHEIEVA, L. M. 2000. Anatomo-tekhnolohichni osoblyvosti formuvannia volokna konopel $i$ vykorystannia yikh $v$ selektsii [Anatomical and technological features of the hemp fiber formation and their use in breeding] : dissertation theses. Kyiv, 16 p. [In Ukrainian].

LAIKO, I.M. 2012. Teoretychni i praktychni osnovy selektsii zakriplennia odnodomnosti, eliminatsii kanabinoidiv ta pidvyshchennia produktyvnosti konopel [Theoretical and practical basics of breeding of consolidation of monoecious, elimination of cannabinoids and increase of hemp productivity] : dissertation theses. Kharkiv, 52 p. [In Ukrainian].

LAIKO, I.M. et al. 2013. Nove v pryiomakh rozshyrennia henetychnoho potentsialu konopel enerhetychnoho napriamu vykorystannia [New in methods of expanding the genetic potential of hemp energy in the direction of use]. In Proceedings of the Institute of Bioenergetic Cultures and Sugar Beet, vol. 19, p. 79-82 [In Ukrainian].

LAYKO, I.M., SITNIK, V.P., VIROVETS, V.G. 2000. Nekotorye aspekty izucheniya i sozdaniya geterozisnykh gibridov konopli [Some aspects of the study and creation of hemp heterotic hybrids]. In Breeding, technology of production and primary processing of flax and hemp: Proceedings of the Institute of Bast Crops of UAAS, vol. 1, p. 88-92 [In Russian].

MEDIAVILLA, V., LEUPIN, M., KELLER A. 2001. Influence of the growth stage of industrial hemp on the yield formation in relation to certain fibre quality traits. In Industrial Crops and Products, vol. 13(1), p. 49-56. https://doi.org/10.1016/S0926-6690(00)00052-2

MISHCHENKO, S.V. 2011. Zmina oznak roslyn konopel' u potomstvi samozapylenykh osobyn sortiv seredn'orosiys'koho i pivdennoho typiv [Changes in the characteristics of hemp plants in the self-pollinated generation of the Central Russian and Southern types varieties]. In Plant Breeding and Seed Production, vol. 100, p. 120-130. https://doi.org/10.30835/2413-7510.2011.66536 [In Ukrainian].

MISHCHENKO, S.V. 2013. Uspadkuvannya oznak stati u samozapylenykh liniy odnodomnykh konopel' ta yiyi evolyutsiyni aspekty [Inheritance of sex characteristics in self-pollinated lines of monoecious hemp and its evolutionary aspects]. In Plant Breeding and Seed Production, vol. 103, p. 143-152. https://doi.org/10.30835/2413-7510.2013.54084 [In Ukrainian].

MISHCHENKO, S.V., LAIKO, I.M. 2013. Zmina oznak voloknystosti konopel pid vplyvom samozapylennia [Changing of the fibrous signs as a result of the impact of self-pollination]. In Plant Breeding and Seed Production, vol. 104, p. 86-91. https://doi.org/10.30835/2413-7510.2013.42025 [In Ukrainian].

MISHCHENKO, S.V. 2015. Osoblyvosti uspadkuvannia oznak stati u sortoliniinykh, liniinosortovykh ta mizhliniinykh hibrydiv odnodomnykh konopel [Specifics of sex characters inheritance in variety $\times$ line, line $\times$ variety and interline hybrids of monoecious hemp]. In Plant Breeding and Seed Production, vol. 108, p. 122-130. https://doi.org/10.30835/2413-7510.2015.57382 [In Ukrainian].

MISHCHENKO, S.V., KMETS, I.L., LAIKO, I.M. 2015. Zmina anatomichnoi budovy lubu Cannabis sativa L. pid vplyvom inbrydynhu [Change of anatomical structure of Cannabis sativa L. bast as a result of inbreeding]. In ScienceRise, vol. 11/6(16), p. 47-50. https://doi.org/10.15587/23138416.2015.54810 [In Ukrainian].

MISHCHENKO, S.V. 2016a. Riven proiavu ta uspadkuvannia selektsiinykh oznak u sortoliniinykh, liniinosortovykh i mizhliniinykh hibrydiv $\mathrm{F}_{1}$ riznykh ekoloho-heohrafichnykh typiv [Expression and inheritance of breeding characters in variety $\times$ line, line $\times$ variety and interline $\mathrm{F}_{1}$ hemp hybrids of different eco-geographical types]. In Plant Breeding and Seed Production, vol. 109, p. 101-110. https://doi.org/10.30835/2413-7510.2016.742052 [In Ukrainian].

MISHCHENKO, S.V. 2016b. Vmist kanabinoidiv u sortoliniinykh, liniinosortovykh i mizhliniinykh hibrydiv konopel $\mathrm{F}_{1}-\mathrm{F}_{3}$ ta metodychni aspekty yikh stvorennia [Cannabinoids content in variety $\times$ line, 
line $\times$ variety and interline hemp $\mathrm{F}_{1}-\mathrm{F}_{3}$ hybrids and methodical aspects of their creation]. In Bulletin of the Center for scientific support of the APV of the Kharkiv region, vol. 21, p. 186-194 [In Ukrainian].

MISHCHENKO, S.V. 2017. Efekty zahalnoi ta variansy spetsyfichnoi kombinatsiinoi zdatnosti samozapylenykh linii i sortiv konopel u systemi topkrosiv [Effects of total and variances specific combining ability of hemp inbred lines and varieties in topcross systems]. In Factors in experimental evolution of organisms, vol. 21, p. 62-67 [In Ukrainian].

MISHCHENKO, S.V., KMETS, I.L. 2017. Minlyvist anatomichnoi budovy voloknystykh struktur na poperechnomu zrizi stebla riznykh zrazkiv konopel [Variability of anatomical structure of fiber on the stem cross-section of the hemp different samples]. In Plant Breeding and Seed Productionon, vol. 112, p. 82-93. https://doi.org/10.30835/2413-7510.2017.120425 [In Ukrainian].

MISHCHENKO, S. et al. 2017. Phenological growth stages of hemp (Cannabis sativa L.): codification and description according to the BBCH scale. In Agricultural sciences, vol. 24(2), p. 31-36. https://doi. org/10.6001/zemesukiomokslai.v24i2.3496

MYHAL, M.D. 2011. Biolohiia lubianykh volokon konopel [Biology hemp bast fibers]. Sumy : Papirus. 390 p. ISBN 978-966-2458-66-4 [In Ukrainian].

ONUPRIIENKO, L.H. 2008a. Vzaiemozviazky mizh anatomichnymy strukturamy stebel ta osnovnymy selektsiinymy oznakamy u suchasnykh vysokovoloknystykh sortiv konopel [The relationship between the stem anatomical structures and the main selection signs in modern high-fiber hemp varieties]. In Proceedings of Uman State Agrarian University, p. 127-133 [In Ukrainian].

ONUPRIIENKO, L.H. 2008b. Efektyvnist doboru na zbilshennia vmistu volokna pry zberezhenni mekhanichnoi funktsii stebla konopel [Efficiency of selection for increasing the fiber content while maintaining the mechanical function of the hemp stem] : dissertation theses. Kharkiv, $20 \mathrm{p}$. [In Ukrainian].

SNEGIREVA, A. et al. 2015. Intrusive growth of primary and secondary phloem fibres in hemp stem determines fibre-bundle formation and structure. In AoB PLANTS, vol. 7, plv061, p. 1-14. https:// doi.org/10.1093/aobpla/plv061

VIROVETS, V.G. 2015. Selektsiya nenarkoticheskoy posevnoy konopli [Breeding of non-narcotic hemp]. Sumy : Ellada. 332 p. ISBN 978-966-1684-64-4 [In Russian]. 